\title{
Options for maintaining fishery production in the United Arab Emirates due to climate change adaptation strategies
}

\author{
Eihab Fathelrahman ${ }^{1 *}$, Khalid Siddig', Saif Al-Qaydi ${ }^{3}$ Safdar Muhammad' Rafi Ullah Tasbih Ullah' \\ ${ }^{1}$ Department of Agribusiness, College of Food and Agriculture, United Arab Emirates University, P.O. Box 15551, Al Ain, United Arab Emirates, \\ ${ }^{2}$ Department of Agricultural Economics, Humboldt-Universität zu, Berlin, Germany, ${ }^{3}$ Department of Geography and Urban Planning, College of \\ Humanities and Social Sciences, United Arab Emirates University, P.O. Box 1555, Al Ain, United Arab Emirates
}

\section{A B S T R A C T}

\begin{abstract}
Fisheries around the world continue to face high demand for more fish to catch in order to offer a healthier alternative source of protein. This is mostly due to the declining global wild fish stock. The United Arab Emirates (UAE), similar to many other countries, has witnessed declining per capita fish availability in the last three decades due to such decreasing fish catch. The goal of this research is to study the benefits and socio-economic implication of adopting sustainable practices in face of climatic uncertainty in the UAE. More specifically, the study undertakes impact analyses of efforts made to sustain such valuable natural resource endowment, i.e., the fish stock. The sustainable practices of the fisheries sector include both hard and soft measures. Hard measures include construction of artificial fish habitats in the Arabian Gulf and the Gulf of Oman. Meanwhile, soft measures include enforcement of regulations that protect and conserve the fisheries' stocks. The economic impacts of these practices are evaluated assuming targeted shiftsbased on assumned scenarios of adaptations measures. To achieve the research objective empirical UAE economic data and Computable General Equilibrium (CGE) model used to perform the analysis. Results show that prices of fishery products and of other related commodities will decline which will benefit the consumers the most. Producers in all relevant directly and indirectly related economic sectors gain due to more sales, which offsets economic losses caused by the lower fish prices. Returns to factors of production, such capital, and labor, also change from sustainable practices. To measure these impacts this study measures the changes in consumer and producer welfare in the UAE due to the simulated targeted interventions. The limitation of such proposed climate change adaptation impact is that fishermen are profit maximizers and so they may underinvest in sustainable adaptations to climate change which implies that public sector (e.g. government) should play a positive role to sustain fisheries sectors practices in the long-term.
\end{abstract}

Keywords: Fisheries; Fish stock; Sustainable practices; Socio-economic impacts; Climate change; United Arab Emirates

\section{BACKGROUND}

The United Arab Emirates (UAE) is located at the southern end of the Arabian Gulf. The country has sea shores at the Arabian Gulf and Gulf of Oman. Fishing is one of oldest traditional industries in the UAE. As a result of its geographical location on an open water outlet (the Indian Ocean), people in the UAE practiced fishing as part of their daily routine for decades. In 2014, the UAE was estimated to have a population of 9.5 million people (World Bank, 2015), which is a large increase from its population in 1980 of 1 million people. The fisheries sector is considered to be the oldest economic sector in the country and before the discovery of oil, fishing was considered to be the main source of income for communities who lived at cities adjacent to shorelines. In the early 1970s, there were only 930 fishing boats and 3,570 fishermen operating in the UAE (UAE Ministry of Planning, 1987). In the late 1970s after the independence of the UAE on December 1971, several economic aspects of peoples' lives in the UAE drastically changed, including the development of fishing activities in terms of the type of gears used and the quantity and quality of the fish catch (Shihab, 2014). In 2011, fishermen were reported to have exceeded 21,000 and the number of fishing boats was reported to have reached 5,963, catching about 79,610 tons of fish (UAE Ministry of Water and

\footnotetext{
${ }^{*}$ Corresponding author:

Eihab Fathelrahman, Department of Agribusiness, College of Food and Agriculture, United Arab Emirates University, P.O. Box 15551, Al Ain, United Arab Emirates. E-mail: Eihab.Fathelrahman@uaeu.ac.ae
}

Received: 05 July 2017; Accepted: 23 January 2018 
Environment, 2014). These significant increases in fishing activities have had a number of positive and negative consequences that are discussed in this research.

Due to major socio-economic developments in the UAE after the first shipment of oil left Dass Island, Abu Dhabi in 1962, the UAE economy attracted millions of people from around the world to participate in its economic development, including the development of the fisheries sector to satisfy a greater demand for food. This development caused structural economic changes, including efforts by the government to develop all economic sectors in the UAE to build a modern and diversified economy, while maintaining strategic objectives, such as a stable food and food security. Rapid economic development introduced changes in peoples' daily lives, such as expanded education, enhanced health services, and higher per capita income. UAE gross domestic product (GDP) per capita converted to international dollars using Purchasing Power Parity (PPP) values is reported to have reached US\$ 59,845 in 2009 (World Bank, 2014) where (where $\$ 1=3.658$ Arab Emirates Dirham AED). This contributed to a significant increase in the demand for food, including the demand for protein commodities such as fish. In addition, increased awareness of the benefits from consuming healthy foods has also increased the demand for fish in the last three decades.

\section{Socio-economic characteristics of the UAE fisheries sector}

Despite the expansion of the UAE's fishery industry in the last three decades, the total fish catch has declined since the early 1990s due to a number of factors, including overfishing, pollution in the Arabian Gulf, and uncertain climatic conditions. The government is determined to sustain fishing activities. Therefore, new fishing rules, regulations, and standards have been introduced in the country. Coastal local fishermen have been replaced by foreign workers who are available to work at lower wages. These foreign workers come into the fishing industry with no or little knowledge of the UAE fishing traditions and with no or very limited fishing skills. These conditions led to the depletion of fishing resources due to overfishing practices such as fishing during fish breading seasons (AlQaydi, 2008) and see Appendix 2. To support the fishing sector in the coastal areas of the UAE and to assure that the sector continues to provide local markets with the sufficient fish supply the UAE government provides support to fishermen, such as by providing fishing gears, equipment loans, and fishing tools, as well as by constructing new fishing harbors. The fish catch reached a peak of 100,000 tons in 2006 but declined in to 72,700 tons in 2012 (Table 1). Meanwhile, the value of the fish catch in the UAE in 2012 is estimated to be 1.2 million AED. The quantity of the fish catches and their corresponding monetary values are depicted in Appendix 1, while the development of the fish self-sufficiency ratio in the UAE from 1982 to 2012 is in Appendix 2. The fish self-sufficiency ratio was estimated to be $91 \%, 128 \%$, and $38 \%$ in 1982, 1991, and 2012, respectively. This indicates that in recent years, the fisheries industry in the UAE is facing extreme challenges as the fish catch is significantly declining. Furthermore, The UAE Ministry of Environment and Water (MOEW) estimates that the value of fish in 2012 is about 1.2 million AED, compared to 0.9 million AED in 2006, while the quantity of fish catch declined from 100,000 tons in 2006 to about 73,000 tons in 2012 (declined by $27 \%$ in six years). These statistics indicate that consumers in the UAE are negatively affected from a reduced availability of fresh fish and relatively higher fish prices.

As illustrated in Table 1, most of the fish catch is from Abu Dhabi, Fujairah, Sharjah, and Ras-Al-Khaimah. According to the Food and Agriculture Organization (FAO) (2013), the most productive areas are close to the Straits of Hormuz and in the Sharjah and Ras-Al-Khai mah Emirates. Fishing is a traditional economic activity affected by recent economic development in the UAE. One of these developments is massive urbanization, involving the building of new residential areas and the creation of tourism facilities that invaded coastal areas and displaced most fishing communities. As a result, the fishing industry in the UAE is facing several sustainability challenges, such as identifying approaches to maintain a stable fish stock and identifying and eliminating unsustainable fishing practices in the country.

In addition to all of the above socio-economic characteristics, sustainable global fish practices and increased movement of trading vessels has led fishermen to leave the fishing industry for other activities. In recent years, both the quantity and quality of fish consumption has increased from increases in the UAE population and the massive expansion of its main cities, e.g., Dubai, Abu Dhabi, and Sharjah. The total value of the fish catch in the UAE increased from less than $\$ 20$ million (1 dollar $=3.76$ AED) in the early 1950 s to more than $\$ 120$ million in the early 2000s. However, the value of the fish catch declined to less than $\$ 100$ million in the late 2000s. These statistics indicate that the fisheries industry in the UAE is unsustainable, with a declining catch that is caused by several factors, including overfishing, pollution in the Arabian Gulf, and market competition from imported fish (Us, 2014).

There are more than 30 designated landing sites along the coast of the UAE. The fish catch is normally auctioned at the fish market in which the ships land. Landing sites incorporate facilities for landing, storing, auctioning, 
Fathelrahman, et al.

Table 1: Annual fish catch quantities by Emirate, 2006-2012 (in Tonne)

\begin{tabular}{|c|c|c|c|c|c|c|c|}
\hline Emirate & 2006 & 2007 & 2008 & 2009 & 2010 & 2011 & 2012 \\
\hline Abu Dhabi & 5,541 & 5,336 & 5,362 & 5,977 & 6,333 & 3,922 & 4,399 \\
\hline Dubai & 7,169 & 6,904 & 6,551 & 10,078 & 8,948 & 8,060 & 11,830 \\
\hline Sharjah & 31,414 & 30,158 & 18,059 & 18,995 & 18,487 & 18,650 & 16,894 \\
\hline Ajman & 4,865 & 4,685 & 5,150 & 5,503 & 5,892 & 6,700 & 6,360 \\
\hline Umm Al - Quwain & 1,075 & 1,045 & 4,996 & 7,681 & 6,649 & 5,735 & 5,490 \\
\hline Ras Al-Khaimah & 29,105 & 27,941 & 18,755 & 17,199 & 17,898 & 17,412 & 16,673 \\
\hline Fujairah & 21,234 & 20,384 & 15,203 & 12,272 & 15,403 & 14,668 & 11,082 \\
\hline Total for the UAE & 100,403 & 96,453 & 74,076 & 77,705 & 79,610 & 75,147 & 72,728 \\
\hline
\end{tabular}

Source: United Arab Emirates Bureau of Statistics, 2016 - See Appendix 2

wholesaling, and retailing the fish catch. Some of the larger landing places and markets have processing facilities for selling to wholesale and directly to retail customers. Even though some imported and shipped products are sold in markets, locally caught fish is mostly locally marketed. The FAO (2013) states that two types of vessels are used to fish in the UAE. One type is a wooden vessel, which is locally manufactured up to about 15 meters in length and primarily operates fish traps (locally known as gargoor). The second type is a fiberglass outboard powered vessel up to eight to ten meters in length (locally known as tarads) that use a variety of gear, including fixed and floating gill nets, hand trolling, drop lines, and gargoor. Vessels that operate gargoor generally take four to five day fishing trips, while smaller launches usually take daily trips.

Within this context and due to the alarming decline in the country's fish stock, this study proposes a larger technological change that shifts resources toward enhancing the endowment of fish natural resources. Such a technological change may involve the construction of fishing artificial habitats, supporting conservation zones, building port and dikes, and supporting soft measures, such as information databases that contribute to regulations enforcement, early warning systems, and an increasing array of activities to promote sustainable fishing practices.

\section{Previous studies}

Several studies explored the options related to sustainable fishery practices and their impacts on the sector. Pauly et al. (2002) show that fisheries have rarely been "sustainable", finding that fishing has induced serial depletions that are masked by improved technology, geographic expansion, and exploitation of previously exhausted species lower in the food chain. With global catches declining since the late 1980s, the continuation of present trends will lead to supply shortfalls, which aquaculture cannot be expected to compensate fish supply. The authors suggest that reducing fishing capacity to appropriate levels will require reducing subsidies and zoning the oceans into unfished marine reserves and areas with limited levels of fishing to allow for sustainable fisheries. They conclude that adjusting the fishing effort to an optimum level should generate maximum sustainable yield. Such sustainable maximum yield levels, however, are rarely implemented. Pauly et al. (2002) highlight that fisheries in many parts of the world have expanded their search offshore as well as into deeper waters, moving into untapped resources. The fisheries sector of the UAE is not different than other countries. Al-Qaydi (2008) confirms this. He studies tradition and government policy changes in the UAE's East Coast fishing community by examining changes in recent decades and the marketing of fish, as well as by providing a compressive policy discussion and recommendations to overcome limitations and challenges facing fishing communities in the UAE. Al-Qaydi (2008) also explores possibilities and challenges facing aquaculture in the UAE. Furthermore, he shows that the ethnic composition and fishing tactics of fishermen along the East Coast have changed markedly in recent decades. The study shows that efforts of fishing have expanded in the last two decades and concluded that the fishing industry is facing alarming levels of declining fish stocks. The extreme difficulty in monitoring and enforcing fishing regulations and standards in the country was also noted.

Brander (2007) shows that the current production of global fisheries is estimated to be 160 million tons and is rising as a result of increases in aquaculture production. A number of threats, including unsustainable practices related to capture fisheries and aquaculture, are identified. However, Brander (2007) has low confidence in predictions of future fisheries production because of uncertainty over future global aquatic net primary production and the transfer of this production through the food chain to human consumption. Recent changes in the distribution and productivity of a number of fish species can be ascribed with a high level of confidence to regional climate variability, such as the El Niño-Southern Oscillation. Future production may increase in some high-latitude regions because of global warming and decreased ice cover. However, dynamics in low-latitude regions are governed by different processes and production may decline as a result of reduced vertical mixing of the water column and hence a reduced recycling of nutrients. There are strong interactions between fishing and environmental changes because fishing reduces the 
age, size, and geographic diversity of populations and the biodiversity of marine ecosystems, making both more sensitive to other unsustainable practices.

Allison and Horemans (2006) describes the Sustainable Livelihoods Approach (SLA) and Sustainable Fisheries Livelihood Program (SFLP), showing that both systems combine a conceptual framework with a set of operational principles to provide guidance on policy formulation and development practice. The SFLP involves 25 West African countries. The authors show that the SFLP has helped align fisheries policies with wider poverty reduction initiatives (e.g. institutional capacity and policy development with both hard and soft measures) and to identify a means of contributing to poverty reduction that do not directly increase pressure on fully or over-exploited fish resources. The authors recommend improving the efficiency of existing systems for producing, processing, marketing, and distributing fish and fish products. In a study titled Anh et al. (2014) show that Vietnamese fisheries have developed rapidly in the last few decades and have significantly contributed to socio-economic development. However, the authors question how sustainable development can be achieved due to lack of effective fisheries management and propose that the industry should balance human and ecological well-being and combine fisheries ecological, social, and economic constraints.

Fisheries are inherently variable and subject to unexpected climatic shocks. Due to such uncertainties, fishers, their communities, and regulators have developed ways to adapt to climate change. Some changes may be positive for some areas and targeted populations, but the current state of knowledge suggests that for many fisheries the effects will be undesirable (Brockmeier, 2001). There are multiple strategies available for fisheries management such as regulations, assignment of property rights, (Fulton et al., 2014). Ecosystem-based management (EBM) is an environmental management approach that recognizes the full array of interactions within an ecosystem, including humans, rather than considering single issues, species, or ecosystem services in isolation (Christensen et al., 1996).

The challenge that faces the fisheries sector and its stakeholders in United Arab Emirates is to answer the question of when and how to adapt when confronted with the inherent climate changes uncertainties of marine ecosystems. Risk management that (1) incorporates an assessment of current and future vulnerabilities; (2) engages stakeholders; and (3) models and simulates different states of the world and strategies, should be used to guide decision makers when responding to climate change (Grafton, 2006). (4) development of management strategy evaluation (MSE) as tool that helps managers identify the tradeoffs across a range of management objectives. In studies based on MSE, usually, the following key steps are involved; a. Specifying management objectives, b. Developing performance measures for each objective, c. Identifying a range of management strategies (and contextual scenarios), d. Predicting the consequences of applying each management strategy, and e. Evaluating trade-offs and communicating with decision makers. In this research, we follow the direction proposed by others and introduce selected climate change adaptation hard and soft measures and assess the impact of such socio-economic measures on the fisheries producers and consumers in the UAE.

Other authors assessed market-based/management climate changes adaptation measures. For example, Fulton et al. (2014) used simulation based approach and the Atlantis modelling framework to evaluate four management strategies; the 2003 status quo, enhanced quota management, integrated management, and conservation dominated management. The results of their research indicated that focusing on individual management measures and simplistic strategies will be inadequate to meet the ecological, economic and social objectives that must be addressed for successful ecosystem based management. Our results show that successful system level management is possible and that it can be jointly uncovered by bringing together options proposed by all parties with a stake in fisheries - industry, conservation, community, scientists and managers.

One of the basic ingredients for fisheries management and policy is the national fisheries performance report. In most countries, this report is prepared at regional/jurisdictional levels. Flood et al. (2016) reports that, in Australia, wild-capture fisheries are managed by eight separate jurisdictions. Fisheries performance reports (e.g. stock status, thresholds, and terminologies), traditionally, are also produced separately by most of these jurisdictions. Usually, these reports differed in their technical specifications and these differences complicate efforts to understand stock status on a national scale. They also create potential misunderstanding among the wider community about how to interpret information on the status of fish stocks and the fisheries management. This is especially true when considering stocks that are shared across two or more jurisdictional boundaries. The paper of Flood et al. (2016) share the experiences of Australia by adopting a standardized approach since 2011 and claims a number of benefits associated with the national level fisheries performance report. For example, the authors claim that the standardized Australian fish stocks reports has enabled stakeholders to easily make comparisons across stocks and jurisdictional boundaries. This approach has also improved 
Australia's ability to provide information at the international level for comparisons. Additionally, regional reports usually named the same species variously and the standardized reporting system has also resolved this issue. This has, in turn, reduced confusion, strengthens consumer confidence and contributes to market efficiency.

In summary, previous studies show that unsustainable practices threaten the economic activities of coastal areas due to declining fisheries stock. In this study, we focus on investigating the impacts of sustainable practices represented by technological change that is leading to an increased natural resource endowment of fisheries in the UAE that may lead the fisheries to be more capable of sustaining the fish stock to conserve such a valuable resource endowment. In this study, we also focus on building a missing link, in previous studies between the fish stock decline and needed economic structural changes at the sectoral level. The underline assumption in the economic model below, addresses such changes, in scenarios format for the fisheries sector labor, capital, and the natural endowment (fish stock).

\section{DATA AND METHODS}

The goal of this research is to study impacts of sustainable practices on the UAE fisheries sector by considering socioeconomic impacts of possible best adaptation options in relationship to climate change. These adaptations require structural changes on factors of production (capital, labor, and natural resource endowment). This research investigates the economic and societal impacts of alternative sustainable practices and sustainable adaptation strategies that are technically sound, socially sustainable, and economically feasible in the UAE, which aim at increasing the natural resource endowment of fish stocks. The research considered two levels of adaptation scenarios aiming increased natural endowment of fish stock are be achieved in response to climate changes. Examples of sustainable practices include constructing artificial fishing habitats, supporting conservation zones, building ports and dikes, and supporting soft measures, such as information dissimination that supports regulations enforcement, the development of early warning systems, and the expansion of activities to promote sustainable fishing practices.

\section{Method}

To achieve this research goal, two climate change adaptation scenarios are considered to illustrate the impact of changes in fisheries sectors factors of production. Factors of production include capital, labor, and natural resource endowment (fish stock): A) increasing the fish stock available for fisheries by $15 \%$ (hereafter, scenario 1) due to moderate climate change adaptation where no external investment is assumed; and B) increasing the fish stock by $30 \%$ which assume increasing the capital endowment for the fisheries sector by $15 \%$ and the labor endowment by $5 \%$ (hereafter, scenario 2) due to the need external added investment. Data source for UAE economy sectors activities (including the fisheries sector) and factors of production obtained from the Global Trade Analysis Project is the GTAP Data Base 9. This study then analyzes expected socio-economic consequences of changes in the factors of production, production, consumption, and trade of all UAE relevant directly or indirectly connected to the UAE fisheries sector. These assumptions are based on the fact that structural technological changes are needed for the fisheries to overcome declining fish stock in the country. The country is already adapting strategies with specific sustainable actions, such as providing free fingerlings and increasing fish stocks by applying measures such as prohibiting fishing during certain seasons and in certain zones. For example, Feary et al. (2011) considered the ecological impact of the development of artificial marine habitats in the Arabian Gulf in a review of current use, benefits, and management implications. The authors note increasing evidence that suggests that abundant and diverse communities of reef fish and coral can develop important ecological implications in urbanized coastal areas in the Arabian Gulf. However, their research argues for more physical measures that include increasing dikes, constructing efficient drainage systems, and providing soft measures, such as early warning systems. Hard and soft measures such as these enhance the natural resource endowment as a factor of production for the fisheries sector in the UAE. The expected beneficiaries of our research include advocates of sustainable practices related to fisheries, the research community in the UAE, policy and decision makers, and fisheries community organizations.

This section describes the model applied and the UAE data used to calibrate the model. Benefiting from the consistent model structure that comes with a comprehensive global database, including the natural resource endowment, this study applied the global Computable General Equilibrium (CGE) model of the Global Trade Analysis Project (GTAP). The GTAP modeling framework comprises of a comparative static CGE model and a global database known as the GTAP database. The model is based on neoclassical theory and its production sectors adopt the assumption of Constant Returns to Scale (CRS). The model also assumes perfect competition among firms and differentiates products by their economy of origin (i.e., the Armington assumption).

The model has a single representative household for each region, called the regional household, which is designed to 
replace all of the regular institutions in the single country CGE model. Therefore, this single representative collects income from factor payments, collects tax revenues net of subsidies, and spends the remainder on private household expenditure, government expenditure, and savings applying a Cobb-Douglas per capita utility function. The private household maximizes its utility subject to its expenditure constraint, which is modeled as a Constant Difference of Elasticity (CDE) demand system. Households spend their generated income on consumption of domestic and imported commodities with a Constant Elasticity of Substitution (CES) function. The CES function is also applied to aggregate goods that are sourced from different regions included in the database. Taxes paid by households include commodity taxes levied on domestically produced as well as imported goods, and income taxes net of subsidies. Government expenditures are allocated according to a Cobb-Douglas sub-utility function (Hertel \& Hertel, 1997).

The major source of income for producers is selling their output to consumers and as intermediate inputs to other producers in the domestic market and/or abroad. Producers spend their collected income on buying intermediate inputs, paying production factors, and paying taxes (i.e., regional household). Therefore, producers satisfy the zero-profit assumption. Every industry is assumed to produce a single output and, as stated earlier, CRS prevails in all markets. These assumptions and the methodological framework enable the examination of the research question to simulate various options of technological change in the UAE fisheries sector.

In the GTAP model, producers maximize profits by rationally paying for two broad categories of inputs, namely, primary factors of production (value added) and intermediate inputs. These two categories are combined using a CES functional form. The value-added category comprises of the various factors of production, including labor, capital, land, and natural resources, that are aggregated using a CES function. On the other hand, the intermediate inputs composite is a Leontief function of the different inputs. These intermediate inputs are sourced either from the domestic market or from imports based on a CES function. Furthermore, imported intermediate inputs are sourced from different regions of the world (depending on the level of aggregation of the world's regions) and the CES functional form is again applied (Brockmeier, 2001). In this study, a factor market closure assumes that total supplies for land and labor are fixed in each region and that capital is mobile across regions depending on its rate of return in each region. The model closes by assuming that the demand for investment in a particular region is driven by savings. The global savings (saving of different regions) contribute to a global pool of homogenous savings, from which these savings are allocated among regions in response to investment demand, which is governed by the relative rates of return to capital in each region (Hertel \& Hertel, 1997).

In this study's model, full employment of the four factors of productions (capital, labor, land, and natural resource endowments) is assumed and businesses operate under perfect competition (zero economic profits) conditions. With respect to mobility, capital and labor factors are assumed to be fully mobile between sectors, while land and natural resource endowments are immobile and hard to move across sectors. The GTAP Database Version 9 is used. It contains 140 regions which are aggregated into two regions, namely, the UAE and the rest of the world (ROW). The base year for the data is 2011 . The 57 sectors (commodities) of the database are kept without aggregation to allow for the monitoring of any possible impacts on sectors that are connected to the fisheries sector. This is particularly important in the case of the UAE fisheries sector due to its relatively small size in the economy. Therefore, any aggregation of the sectors may reduce the magnitude of any change that might be caused by the simulated interventions of the fisheries sector. The five endowment commodities - land, natural resources, capital, unskilled labor, and skilled labor - are also kept without aggregation. The assumption of the mobility of the factors of production enables the tracking of the economic and societal impacts (i.e., shifts from the use of capital and labor endowments to the natural resource endowment) expected from the interventions applied to answer our research question. The GTAP model is widely used to model the impact of technological change, including shifts between factors of production. In this research, a proposed shift from capital and labor factors of production are assumed to cover the technological change required for the costs of sustainable fishery practices, such as the support for artificial habitats, development of conservation zones, and the development of soft measures (e.g., information databases that contribute to the enforcement of regulations and early warning systems) Siddig et al. (2014).

Aguiar et al. (2012) in GTAP database documentation described the direct derivation of the elasticity of supply, for the particular production tree used in GTAP, in which, with standard parameter settings, output is a Leontief aggregate of intermediate inputs and value added, and value added is a CES aggregate of primary factors of production (i.e., capital, labor, and natural resource endowment); with the additional assumption that one primary factor, natural resources, is fixed, and all other inputs are mobile. Let $P i$ and $Q i$ denote the price and quantity of $i$. Let $p i$ and $q i$ denote the corresponding relative differentials. Simulations 
of the Computable General Equilibrium (CGE) production function for the fisheries sector are based on changes to the sectoral response which is simply determined by the fisheries sector ability to substitute away from the fixed factor. This relationship is a function of the cost shares and elasticities of substitution in the nested Constant elasticity of substitution. CES.

$p_{i}=\frac{d P_{i}}{P_{i}}, q_{i}=\frac{d Q_{i}}{Q_{i}}$.

Let $\operatorname{Sij}$ the share of $j$ in the cost of $i$,

$S_{i j}=\frac{P_{j} Q_{j}}{P_{i} Q_{i}}$,

where $i$ and $j$ may take the values $R$ for natural resources, $F$ for primary factors, and $O$ for output. For some industry in some region, let denote the elasticity of supply, and the elasticity of substitution between primary factors. Assume that prices of inputs other than natural resources are constant. Then, from the GTAP equation system, the authors extracted the subsystem

$$
\begin{aligned}
& q_{R}=q_{F}-\sigma_{F}\left(P_{R}-P_{F}\right), \\
& P_{F}=S_{F R} P_{R} \\
& q_{F}=q_{O} \\
& p_{O}=S_{O R} P_{R}
\end{aligned}
$$

in which $p_{0}$ and $q_{\mathrm{R}}$ are given, and from which $P_{\mathrm{R}}, P_{\mathrm{F}}, q_{0}$, and $q_{0}$ may be found. Solving for the unknowns, the authors obtain the supply equation

$$
q_{O}=q_{R}+\sigma_{F} \frac{1-S_{F R}}{S_{O R}} P_{O}
$$

Then the elasticity of supply is the $\mathrm{p}_{0}$ coefficient of in that equation, that is,

$$
\mathfrak{y}_{S}=\sigma_{F} \frac{1-S_{F R}}{S_{O R}}
$$

In this research, the scenario 1 and 2 are based on assumption documented by Hertel et al. (2012) when showed that Campbell (1996) explores this issue in considerable detail for the case of tuna. In the case of an "open access" fishery, anyone seeking to come and harvest the stock of fish can do so. Open access leads to essentially an infinite discount rate, over-fishing, and hence a very low supply response of (0.29). On the other hand, some fisheries are managed by an industry group. When such a group operates as a single, profit maximizing entity, supply is more responsive. In this type of "private management" regime, reductions in the discount rate will increase the responsiveness of supply. In the case of a zero discount rate and private management, Campbell computes supply elasticity for tuna of 0.76 . These represent the two extremes for the tuna industry. For purposes of GTAP 4 , the authors averaged the two and obtain an elasticity of supply equal to 0.525 . Someone studying a question in which fisheries supply response is a crucial parameter could specify a distribution of supply elasticities, based on the Campbell study (e.g., triangular distribution with minimum value 0.29 and maximum value 0.72 ), thereby generating a distribution of possible outcomes. For such reason, this study considered conditions that represents 0.29 supply elasticity for scenario 1 and conditions which represent 0.525 supply elasticity for scenario 2 . To address possible outcomes due to the UAE fisheries options for maintaining a sustainable fishery production three levels of simulated level on the natural resource factors of production endowment are assumed to achieve 29\%, 53\%, elasticity levels were modeled following the various fishing regimes described above (i.e., open access, and mid-range private management regime conditions.

\section{RESULTS AND ANALYSIS}

This results and analysis section provides a description of the expected changes in the UAE fisheries sector and other economic indicators in response to the climate change adaptation scenarios from the baseline. The indicators and variables that are used to illustrate the impacts of the policy scenarios are grouped into six major categories, which constitute the six subsections of the following section, are as follows: 1) production quantities; 2) real prices of production factors; 3 ) prices of fish and other affected commodities; 4) prices of value-added prices paid by industries; 5) the UAE's trade values; and 6) household demand for commodities. All changes are shown in percentage changes from the baseline (i.e., the status quo). The results and analysis section is followed by the conclusions section.

\section{Changes in production quantities}

Starting from a fish catch of 72,700 tons in 2012, scenario 1 (an increase in the natural resource endowment by $15 \%$ from the baseline) leads to a percentage increase of $7.8 \%$ (i.e., an increase in production to 78,4000 tons). Meanwhile, scenario 2 (an increase in the natural resource endowment by $30 \%$, capital by $15 \%$, and labor by $5 \%$ ) leads to a percentage increase of $15.1 \%$ (i.e., an increase in production to 83,700 thousand tons). These results indicate the importance of an increase in the natural resource endowment of fisheries in the UAE. These results imply that increasing efforts on 
the natural resource endowment as a factor of production causes other factors of production to be more efficient in fish production. As far as production is concerned, scenarios 1 and 2 result in no changes in the other sectors of the UAE economy, with the exception of a very small change of $0.1 \%$ in the food processing sector (Figure 1). These results indicate that overall production increase and producers in all relevant economic sectors have more sales, which offset losses from declining fish prices. In other words, the adoption of sustainable fishing practices reduces fish prices but increases the value-added of other related economic sectors. Overall, sustainable practices lead to increased output of the UAE food sector.

\section{Changes in real prices of production factors}

Table 2 shows the percentage changes in the real prices of production factors (deflated by the consumer price index) under scenarios 1 and 2 from the baseline. As expected, prices of the natural resources endowment decline by $0.100 \%$ and $0.157 \%$ in scenario 1 and scenario 2 , respectively, which are justified by the increase in the availability (supply) of production factors triggered by improved efficiency. The demand for other factors of production would also increase, including the demand for land and labor to complement the increased/available natural resource endowment. Land prices increases by $0.016 \%$ and $0.03 \%$ in scenario 1 and scenario 2 , respectively. Meanwhile, changes in labor prices (wages) are relatively small. These results indicate that the efforts of preserving a sustainable natural resource endowment in the fisheries sector increase the demand for and prices of other factors of production.

\section{Changes in prices of fish and other commodities}

The composite price of fish (both domestically produced and imported fish) declines by $7.7 \%$ and $13.68 \%$ in scenario 1 and scenario 2, respectively. Considering the domestically produced/caught fish separately, the decline in its price is $10.07 \%$ and $17.67 \%$ in scenario 1 and scenario 2 , respectively. Meanwhile, prices of imported fish are not expected to significantly change in both scenarios 1 and 2 . These results show that the consumer fish price is highly influenced by changes in the factors of production used in the fisheries sector, especially when adopting sustainable practices that enhance the supply of the natural resource endowment (Figure 2).

The decrease in the fish price is expected to motivate consumers to demand more fish and less fish substitutes, such as red meat and other meat products (e.g. poultry products). This causes red meat producers to offer red meat at lower prices. The commodity price of red meat and other meat products composite (both produced locally and imported) price decreases by $0.02 \%$ and $0.04 \%$ in scenario 1 and scenario 2 , respectively. The commodity price of domestically-produced red meat decreases by $0.03 \%$ and 0.06 in scenario 1 and scenario 2, respectively. This indicates that sustainable practices that enhance the natural fishery resource endowment of the UAE spill out and benefit the consumer, not only by lowering fish prices but also by lowering prices of fish substitutes such as other meat products. A similar result can be derived when considering changes in dairy products and other food products (Table 3). As expected, socio-economic impacts on the fisheries sub-sector itself would be relatively large compared to those accrued at other food sectors in the UAE. Using a CGE model enables us to reach this

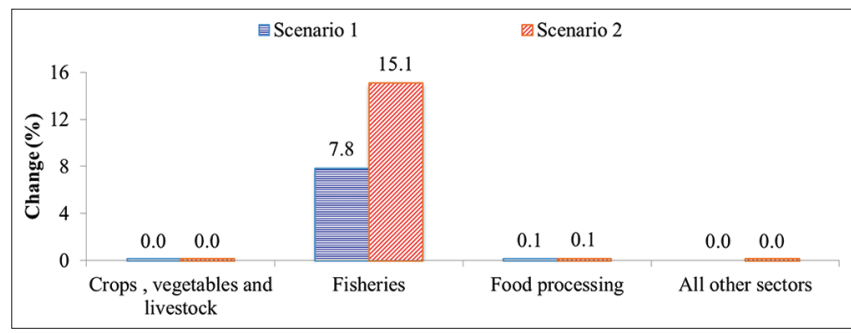

Fig 1. Changes in the commodity output of selected industries (\% from the base). Source: Model results.

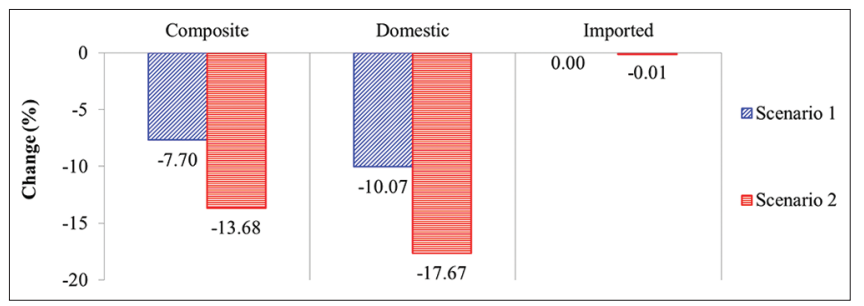

Fig 2. Changes in the private consumption price of fish (\% change from baseline). Source: Model results.

Table 2: Changes in real prices of production factors (\% change from baseline)

\begin{tabular}{|c|c|c|c|c|c|}
\hline \multirow[t]{2}{*}{ Factor of production } & \multirow[t]{2}{*}{ Scenario 1} & \multicolumn{4}{|c|}{ Scenario 2} \\
\hline & & Combined factors & Natural resources & Capital & Labor \\
\hline Land & 0.016 & 0.030 & 0.026 & 0.004 & 0.000 \\
\hline Unskilled labor & 0.006 & 0.011 & 0.009 & 0.002 & 0.000 \\
\hline Skilled labor & 0.004 & 0.008 & 0.006 & 0.002 & 0.000 \\
\hline Capital & 0.004 & 0.006 & 0.006 & 0.000 & 0.000 \\
\hline Natural resources & -0.100 & -0.157 & -0.161 & 0.004 & 0.000 \\
\hline
\end{tabular}

Source: Model results 
conclusion due to the possibility of exploring not only the direct impacts of sustainable practices but also the indirect and induced economic impacts on the other food sectors and the impacts on both producers and consumers, which is captured by forward and backward linkages.

Changes in prices paid by firms to production factors As shown in Table 4, the largest changes in prices paid by firms to factors of production (land, unskilled labor, skilled labor, capital, and natural resources) under our assumptions and scenarios occur in natural resource endowments. The price paid by firms to natural resources declines by $38.7 \%$ and $62.2 \%$ in scenario 1 and scenario 2 , respectively. This decline is driven by an increase in their supply, which is simulated to increase. The price of land increases by $1.1 \%$ and $1.2 \%$ in scenario 1 and scenario 2 , respectively, which indicates higher demand for land to accommodate for the corresponding change in natural resources.

\section{Change in merchandize trade}

Results of scenario 1 and scenario 2 reveal that the value of fish exports will increase by $13.48 \%$ and $25.77 \%$, respectively. However, the value of fish exports was very small in 2012 (the base year), which was estimated to be $\$ 31,000$. On the imports side, fishery imports decline by $6.64 \%$ and $11.75 \%$ in scenario 1 and scenario 2 , respectively (Appendix 3). The base value of fish imports is $\$ 47.5$ million (Figure 3).

\section{Change in household demand for commodities}

The results indicate an increase in the quantity of commodity fish demanded (a composite of domesticallyproduced and imported fish commodities) by $5.62 \%$ and $10.57 \%$ in scenario 1 and scenario 2, respectively.
Household consumption of domestically-produced fish increases by $9.12 \%$ and $17.31 \%$ in scenario 1 and scenario 2 , respectively. On the other hand, consumption of imported fish declines by $4.43 \%$ and $7.99 \%$ in scenario 1 and scenario 2, respectively. These results portray a favorable situation for consumers because consumers in both scenarios can consume more fish commodity and pay lower fish commodity prices, which could be justified on the basis of the adopted sustainable practices in the UAE fisheries sector.

To summarize, the technological changes suggested from this research enhance the economic situation of both consumers and producers of fish in the UAE. Although producers in the fisheries sector face a declining fish price, the overall impact of the two policy scenarios on the entire UAE's food sector is positive.

\section{CONCLUSIONS}

The goal of this research is to evaluate the economic options of sustainable practices in the fisheries sector under

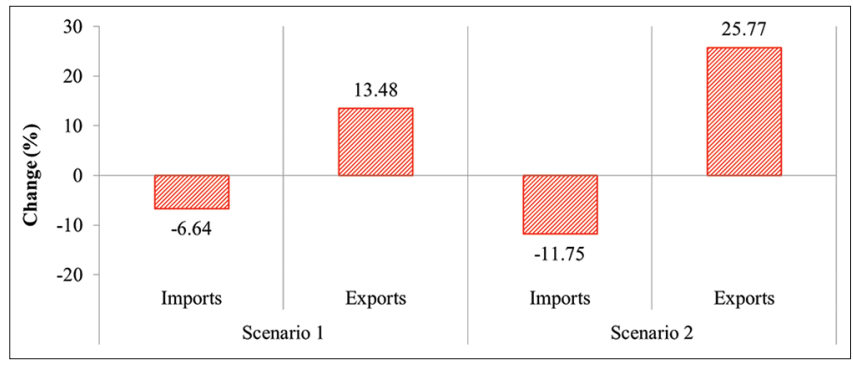

Fig 3. Changes in merchandize fishery trade (\% change from baseline)

Table 3: Changes in private consumption prices of selected commodities ( $\%$ change from baseline)

\begin{tabular}{|c|c|c|c|c|c|c|}
\hline \multirow[t]{2}{*}{ Commodity } & \multicolumn{3}{|c|}{ Scenario 1} & \multicolumn{3}{|c|}{ Scenario 2} \\
\hline & Composite & Domestically produced & Imported & Composite & Domestically produced & Imported \\
\hline Other animal products & 0.00 & -0.01 & 0.00 & -0.01 & -0.01 & 0.00 \\
\hline Raw milk & -0.03 & -0.03 & 0.00 & -0.05 & -0.05 & 0.00 \\
\hline Fishing & -7.70 & -10.07 & 0.00 & -13.68 & -17.67 & -0.01 \\
\hline Meat production & -0.02 & -0.03 & 0.00 & -0.04 & -0.06 & 0.00 \\
\hline Other meat products & 0.00 & -0.01 & 0.00 & -0.01 & -0.02 & 0.00 \\
\hline Vegetable oils and fats & 0.00 & -0.02 & 0.00 & 0.00 & -0.03 & 0.00 \\
\hline Dairy products & -0.01 & -0.03 & 0.00 & -0.02 & -0.05 & 0.00 \\
\hline Processed rice & 0.00 & -0.03 & 0.00 & 0.00 & -0.05 & 0.00 \\
\hline Other food products & -0.03 & -0.05 & 0.00 & -0.05 & -0.08 & 0.00 \\
\hline $\begin{array}{l}\text { Beverages and } \\
\text { tobacco products }\end{array}$ & -0.01 & -0.03 & 0.00 & -0.02 & -0.06 & 0.00 \\
\hline
\end{tabular}

Source: Model results

Table 4: Changes in prices paid by firms to production factors (\% change from baseline)

\begin{tabular}{llcccc} 
& Land & Unskilled labor & Skilled labor & Capital & Natural resources \\
\hline Scenario 1 & 1.132 & 0.003 & 0.001 & 0.001 & -38.722 \\
Scenario 2 & 1.241 & 0.005 & 0.002 & 0.000 & -62.161 \\
\hline
\end{tabular}

Source: Model results 
uncertain climatic changes in the UAE. To reach this goal, the specific objectives of this research are two-fold: the first is to evaluate the economic impacts of the options of increasing efforts to enhance the capital endowment for the fisheries sector by 15\% from the baseline which is represented by the 2012 UEA fishery data and no external capital investment; and the second is to study the option of enhancing the capital endowment for the fisheries sector by $30 \%$ from the baseline together with an increase in capital investment by $15 \%$ and in labor availability in the fisheries sector by $5 \%$. The results from these two scenarios show that there is an increase in fish production from the baseline of 72,700 tons in 2012 to 78,400 thousand tons (an increase of $7.8 \%$ ) under scenario 1 and an increase to 83,700 tons (an increase of $15.1 \%$ ) in scenario 2. Prices of production factors used in the fisheries sector, other than the natural resource endowment (capital, labor, land, skilled labor, and unskilled labor) would also increase from increases in their demands. Household consumption of domestically-produced fish increases by $9.12 \%$ and $17.31 \%$ in scenario 1 and scenario 2, respectively.

From policy point of view, this study's scenarios indicate consumers will be able consume more and pay less for fish in both scenarios due to the adaption to the proposed sustainable practices in the UAE fisheries sector in response climate change. Sustainable practices could include both physical and soft measures. Physical measures include building dikes and the construction of well-equipped harbors. Soft measures include early warning systems and the enforcement of regulations that protect and conserve the fish stock. Enhancing the natural resources endowment increases the value of other factors of production, such as land, capital, and labor, in the UAE fisheries sector and benefits both consumers and producers. This initial economic modeling exercise to depict the future sustainable is not without a limitation. Major limitation is that fishermen are profit maximizers and so underinvest in proposed climate change adaptation which necessitates the government to step-in in invest in long term climate changes adaptation practices to assure proper investment in long term sustainability measures. The study can reflect sustainable environment if factor such the capital accumulation and investment impact are considered for the long-term rather than the static conditions portrayed in this study.

\section{REFERENCES}

Aguiar, A., R. McDougall and B. Narayanan. 2012. Global Trade, Assistance, and Production: The GTAP 8 Data Base. Center for Global Trade Analysis, Purdue University, West Lafayette.

Al-Qaydi, S. S. 2008. Tradition, change, and government policy in the United Arab Emirates East Coast Fishing Community. Focus
Geogr. 51(1): 1-6.

Allison, E. H. and B. Horemans. 2006. Putting the principles of the sustainable livelihoods approach into fisheries development policy and practice. Mar. Policy. 30(6): 757-766.

Anh, P. V., G. Everaert, C. T. Vinh. and P. Goethals. 2014. Need for integrated analysis and management instruments to attain sustainable fisheries in Vietnam. Sustain. Water Qual. Ecol. 3: $151-154$.

Aguiar, A., R. McDougall and B. Narayanan. 2012. Global Trade, Assistance, and Production: The GTAP 8 Data Base. Center for Global Trade Analysis, Purdue University, West Lafayette.

Allison, E. H. and B. Horemans. 2006. Putting the principles of the sustainable livelihoods approach into fisheries development policy and practice. Mar. Policy. 30(6): 757-766.

Al-Qaydi, S. S. 2008. Tradition change, and government policy in the United Arab Emirates East Coast Fishing Community. Focus. Geogr. 51(1): 1-6.

Arab Organization for Agricultural Development (AOAD). 2014. Arab Agricultural Statistical Database. CD Version. Available from: http://www.aoad.org/publications.htm. [Last accessed on 2017 Jun].

Brockmeier, M. 2001. A graphical exposition of the GTAP model. GTAP Technical Papers. Purdue University. Purdue e-Pubs. Department of Agricultural Economics. College of Agriculture at Purdue University.

Brander, K. M. 2007. Global Fish Production and Climate Change. Proc. Natl. Acad. Sci. 104(50): 19709-19714.

Brockmeier, M. 2001. A Graphical Exposition of the GTAP Model, GTAP Technical Papers. Purdue University. Purdue e-Pubs. Department of Agricultural Economics. College of Agriculture at Purdue University.

Campbell, H. F. 1996. Prospects for an international tuna resource owners' cartel. Mar. Policy. 20(5): 419-427.

Campbell, H. F. 1996. Prospects for an international tuna resource owners' cartel. Mar. Policy. 20(5): 419-427.

Christensen, N. L., A. M. Bartuska, J. H. Brown, S. Carpenter, C. D'Antonio, R. Francis, D. J. Parsons. 1996. The report of the Ecological Society of America committee on the scientific basis for ecosystem management. Ecol. Appl. 6(3): 665-691.

FAO. 2013. Information on Fisheries Management in the United Arab Emirates. http://www.fao.org/fi/oldsite/FCP/en/ARE/body.htm. [Last accessed on 2013 Oct 17].

Feary, D. A., J. A. Burt and A. Bartholomew. 2011. Artificial marine habitats in the Arabian Gulf: Review of current use, benefits, and management implications. Ocean Coast. Manage. 54(10): 742-749.

Feary, D. A., J. A. Burt. and A. Bartholomew. 2011. Artificial marine habitats in the Arabian Gulf: review of current use, benefits, and management implications. Ocean Coast. Manage. 54(10): 742-749.

Flood, M. J., I. Stobutzki, J. Andrews, C. Ashby, G. A. Begg, R. Fletcher, K. Hartmann. 2016. Multijurisdictional fisheries performance reporting: how Australia's nationally standardised approach to assessing stock status compares. Fish. Res. 183: 559-573.

Food and Agriculture Organization (FAO). 2013. Information on Fisheries Management in the United Arab Emirates. Available from: http://www.fao.org/fi/oldsite/FCP/en/ARE/body.htm. [Last accessed on 2013 Oct 17].

Fulton, E. A., A. D. Smith, D. C. Smith, P. Johnson. 2014. An integrated approach is needed for ecosystem based fisheries management: 
Insights from ecosystem-level management strategy evaluation. PLoS One. 9(1): e84242.

Grafton, R. Q., R. Arnason, T. Bjørndal, D. Campbell, H. F Campbell, C. W. Clark, R. Connor, D. P.Dupont, R. Hannesson. and R. Hilborn. 2006. Incentive-based approaches to sustainable fisheries. Can. J. Fish. Aquatic Sci. 63(3): 699-710.

Hertel, T. W. 1997. Global Trade Analysis: Modeling and Applications. Cambridge University Press, Cambridge.

Hertel, T. W., M. Tsigas and G. B. Narayanan. 2012. Primary factor shares section 12.A, in Ch. 12: Value added. In: Narayanan, G. B., A. Aguiar, R. McDougall (Eds.), Global Trade, Assistance, and Production: The GTAP 8 Data Base, Center for Global Trade Analysis, Purdue University.

Hertel, W, T., M. Tsigas, and G. B. Narayanan. 2012. Primary factor shares section 12.A, in Ch. 12: Value added. In: Narayanan, G. B., A. Aguiar., McDougall, R (Eds.), Global Trade, Assistance, and Production: The GTAP 8 Data Base. Center for Global Trade Analysis, Purdue University.

Hertel, T. W. and T. W. Hertel. 1997. Global Trade Analysis: Modeling and Applications. Cambridge University Press, Cambridge.

Pauly. D., V. Christensen, S. Guénette, T. J. Pitcher, U. R.Sumaila, C. J. Walters. and D. Zeller. 2002. Towards sustainability in world fisheries. Nature. 418(6898): 689-695.

Pauly, D., V. Christensen, S. Guénette, T. J. Pitcher, U. R. Sumaila, C. J. Walters. and D. Zeller. 2002. Towards sustainability in world fisheries. Nature, 418(6898): 689-695.

Sea Around US. 2014. Available from: http://www.seaaroundus.org/ data/\#/eez/784?chart=catch-chart\&dimension=taxon\&measure $=$ tonnage. [Last accessed on $2014 \mathrm{Dec}$ ].

Shihab, M. 2014. Economic Development in the United Arab Emirates (UAE). Available from: http://www.uaeinteract.com/uaeint_misc/ pdf/perspectives/12.pdf. [Last accessed on 2014 Nov 20].

Shihab, M. 2014. Economic Development in the United Arab Emirates (UAE). Available from: http://www.uaeinteract.com/uaeint_misc/ pdf/perspectives/12.pdf.

Siddig, K., A. Aguiar, H. Grethe, P. Minor and T. Walmsley. 2014. Impacts of removing fuel import subsidies in Nigeria on poverty. Energy Policy. 69: 165-178.

United Arab Emirates Bureau of Statistics from Ministry of Water and Environment. 2014. Available from: http://www.uaestatistics.gov. ae/EnglishHome/ReportDetailsEnglish/tabid/121/Default.aspx? temld=2342\&PTID=104\&Menuld for year 2010. [Last accessed on 2014 Nov 25].

United Arab Emirates Ministry of Planning. 1987. Socio Economic Developments in the UAEfrom 1975-1985. Modern Printing Press \& Stationary, Dubai, pp. 101-105.

World Bank. 2014. World Bank Open Data. Per Capita GDP by country. Available from: http://www.data.worldbank.org/indicator/ NY.GDP.PCAP.PP.CD?order=wbapi_data_value_2012+wbapi data_value+wbapi_data_value-last\&sort=desc. [Last accessed on 2014 Dec 26].

World Bank. 2014. World Development Indicators, Online Database, Population Data. Available from: http://www.data.worldbank.org [Last accessed 2017 Aug].

\section{APPENDICES}

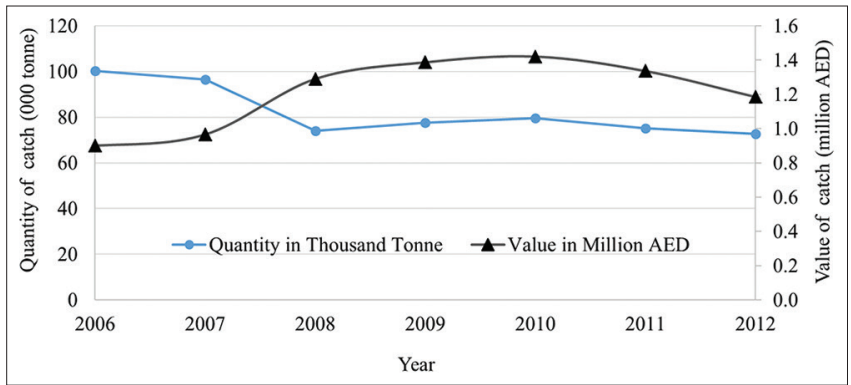

Appendix 1. Fish catch quantity (in '000 tons) and value (in million AED), $2006-2012$

Source. United Arab Emirates Bureau of Statistics, 2014.

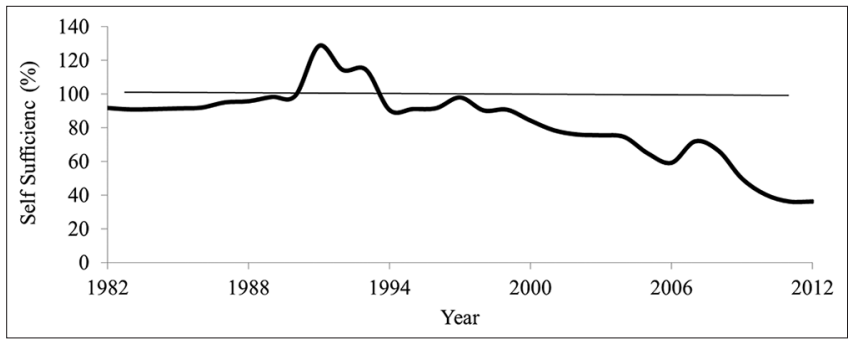

Appendix 2. Fish Self-Sufficiency Ratios in the UAE, $1982-2012$

Source. Arab Organization for Agricultural Development (AOAD), Yearly Statistical Books 1980-2012. 
Fathelrahman, et al.

Appendix 3: Changes in trade values of commodities (\% change from baseline)

\begin{tabular}{|c|c|c|c|c|}
\hline \multirow[t]{2}{*}{ Commodity } & \multicolumn{2}{|c|}{ Value of merchandise imports (CIF) } & \multicolumn{2}{|c|}{ Value of merchandise exports (FOB) } \\
\hline & $\begin{array}{c}\text { Scenario } \\
1\end{array}$ & Scenario 2 & $\begin{array}{c}\text { Scenario } \\
1\end{array}$ & Scenario 2 \\
\hline Paddy rice & 0.03 & 0.06 & 0.00 & 0.00 \\
\hline Wheat & 0.01 & 0.02 & -0.01 & -0.01 \\
\hline Cereal grains nec. & 0.01 & 0.02 & 0.00 & 0.00 \\
\hline Vegetables, fruit, nuts & 0.00 & 0.01 & -0.01 & -0.01 \\
\hline Oil seeds & 0.06 & 0.12 & 0.00 & 0.00 \\
\hline Sugar cane, sugar beet & 0.04 & 0.08 & 0.00 & 0.00 \\
\hline Plant-based fibers & 0.00 & 0.01 & 0.00 & 0.00 \\
\hline Crops nec & 0.02 & 0.03 & -0.01 & -0.01 \\
\hline Live animals production & 0.03 & 0.05 & 0.00 & 0.00 \\
\hline Animal products nec & 0.00 & 0.00 & 0.01 & 0.02 \\
\hline Raw milk & -0.07 & -0.12 & 0.18 & 0.31 \\
\hline Wool, silk-worm cocoons & 0.00 & 0.01 & 0.00 & 0.00 \\
\hline Fishing & -6.64 & -11.75 & 13.48 & 25.77 \\
\hline Minerals nec & 0.00 & 0.01 & 0.00 & 0.00 \\
\hline Red meat production & -0.04 & -0.07 & 0.20 & 0.35 \\
\hline Meat products nec & -0.01 & -0.02 & 0.07 & 0.12 \\
\hline Vegetable oils and fats & 0.00 & 0.00 & 0.09 & 0.16 \\
\hline Dairy products & 0.02 & 0.04 & 0.17 & 0.30 \\
\hline Processed rice & 0.04 & 0.08 & 0.10 & 0.18 \\
\hline Sugar & 0.00 & 0.00 & 0.11 & 0.19 \\
\hline Food products nec & -0.04 & -0.07 & 0.12 & 0.22 \\
\hline Beverages and tobacco products & 0.00 & 0.00 & 0.04 & 0.06 \\
\hline Textiles & 0.01 & 0.01 & 0.00 & 0.00 \\
\hline Wearing apparel & 0.00 & 0.00 & -0.01 & -0.01 \\
\hline Leather products & 0.00 & 0.00 & -0.01 & -0.02 \\
\hline Wood products & 0.00 & 0.01 & -0.01 & -0.01 \\
\hline Paper products, publishing & 0.00 & 0.01 & 0.00 & 0.00 \\
\hline Mineral products nec & 0.00 & 0.01 & 0.00 & 0.00 \\
\hline Ferrous metals & 0.00 & 0.01 & 0.00 & 0.00 \\
\hline Metals nec & 0.01 & 0.02 & -0.01 & -0.01 \\
\hline Metal products & 0.02 & 0.03 & -0.01 & -0.01 \\
\hline Transport equipment nec & 0.00 & 0.01 & -0.01 & -0.01 \\
\hline Electronic equipment & 0.00 & 0.01 & -0.01 & -0.01 \\
\hline Machinery and equipment nec & 0.00 & 0.00 & -0.01 & -0.01 \\
\hline Manufactures nec & 0.00 & 0.01 & 0.00 & -0.01 \\
\hline Gas manufacture, distribution & 0.03 & 0.04 & 0.00 & 0.00 \\
\hline Water & 0.01 & 0.01 & 0.00 & 0.00 \\
\hline Construction & 0.01 & 0.01 & 0.00 & 0.00 \\
\hline Trade & 0.00 & -0.01 & 0.00 & 0.00 \\
\hline Transport nec & 0.00 & 0.01 & 0.00 & 0.00 \\
\hline Sea transport & 0.02 & 0.04 & 0.00 & 0.00 \\
\hline Insurance & 0.01 & 0.02 & 0.00 & 0.00 \\
\hline Business services nec & 0.01 & 0.02 & 0.00 & 0.00 \\
\hline Recreation and other services & 0.00 & 0.00 & 0.00 & -0.01 \\
\hline
\end{tabular}

$\mathrm{ClF}=$ Cost, Insurance and Freight; FOB=Free On Board; nec=not else considered 